Annales Missiologici Posnanienses t. 25 (2020), s. 35-56

doi: $10.14746 / \mathrm{amp} .2020 .25 .3$

ORCID: 0000-0001-9383-2583

\author{
GRZEGORZ ADAMIAK \\ Uniwersytet Kardynała Stefana Wyszyńskiego w Warszawie \\ Wydział Teologiczny
}

\title{
Misyjne nauczanie Jana Pawła II podczas pielgrzymek do Polski
}

Pontyfikat Jana Pawła II, a zwłaszcza jego pielgrzymowanie do ojczyzny, ma duże znaczenie dla Kościoła w Polsce. Z perspektywy lat można śmiało stwierdzić, że stanowią one cenne dziedzictwo pozostawione rodakom przez polskiego papieża (Zagrodzki 9; Ryłko 13). Papieskie nauczanie dotyczyło często typowo polskich spraw i problemów, ale zawsze należy widzieć je w perspektywie papieskiej katechezy dla Kościoła powszechnego (Kłoczowski 17). Mówiąc o charakterystycznych cechach pontyfikatu Papieża-Polaka, wskazuje się m.in. na misyjny rys, który silnie określał nauczanie Jana Pawła II - „misjonarza świata” (Górski; Kluj). Niniejszy artykuł ukazuje obecność wątku misji ad gentes i misyjnego aspektu życia Kościoła w nauczaniu Jana Pawła II podczas jego pielgrzymek do Polski.

\section{Misje u początku państwa i Kościoła w Polsce}

Począwszy od swej pierwszej pielgrzymki do ojczyzny, Papież-Polak wskazywał na ścisły związek początków państwa i narodu polskiego z początkami Kościoła w naszym kraju. Podkreślał, że zbudowano polskie państwo, naród i Kościół na fundamencie misyjnego wysiłku i zaangażowania pierwszych misjonarzy na rodzimych ziemiach, a w szczególności przypieczętowanej męczeństwem pracy misyjnej św. Wojciecha.

Jan Paweł II odczytywał początki pracy misyjnej na ziemiach polskich w kontekście Pięćdziesiątnicy, która zainicjowała obecność uczniów Jezusa Chrystusa aż po krańce ziemi, także wśród ludów słowiańskich. W dniu 3 czerwca 1979 r. tak nauczał w Gnieźnie: 
Otwarł się po stuleciach na nowo jerozolimski wieczernik i zdumiały się już nie ludy Mezopotamii i Judei, Egiptu czy Azji, czy wreszcie przybysze z Rzymu, ale zdumiały się ludy słowiańskie i inne zamieszkujące w tej części Europy, iż apostołowie Jezusa Chrystusa mówią ich językami, że w rodzimej mowie opowiadają „wielkie dzieła Boże” (JP II, Hom. 4, Gniezno 3.06.1979. 33).

Do tego samego wątku Jan Paweł II powrócił w czasie pielgrzymki do Polski w 1997 r., gdy jako początek „świętowojciechowego”, duchowego szlaku wskazał właśnie Wieczernik i misyjny nakaz Jezusa. Zlecenie mandatu misyjnego, przypieczętowane w dniu Pięćdziesiątnicy, rozpoczęło dzieło ewangelizacji świata, które dotarło również na ziemie polskie. Chrzest Mieszka I został potwierdzony męczeńską krwią św. Wojciecha, a dzięki świadectwu tego męczennika rodzące się państwo polskie mogło wejść do rodziny krajów europejskich, co dokonało się symbolicznie podczas Zjazdu Gnieźnieńskiego w 1000 r. (JP II, Hom. 1, Gniezno 3.06.1997. 907-908).

W tej perspektywie papież uznał relikwie św. Wojciecha za największy skarb narodu polskiego (JP II, Hom. 1, Gniezno 3.06.1997. 907). Misjonarska działalność św. Wojciecha w Polsce, z całym dramatyzmem jego losu, stanowi zwieńczenie początków ewangelizacji ziem piastowskich oraz fundament dla Kościoła i państwa polskiego. Z tego zasiewu krwi, przez następne stulecia, Polska obficie czerpała od samego zarania swej państwowości. Dzięki misyjnej pracy św. Wojciecha naród polski zyskał pełne prawo uczestniczenia na równi z innymi narodami w procesie tworzenia nowego oblicza kontynentu europejskiego (JP II, Hom. 2, Gniezno 3.06.1997. 908-909).

Jednoczącą i budującą rolę misyjnego dzieła św. Wojciecha w początkach państwowości i Kościoła w Polsce oraz jego wpływ na narodową tożsamość Jan Paweł II uwypuklił również na spotkaniu z polskimi biskupami w czasie pierwszej pielgrzymki do Polski (JP II, Przem. 2, Częstochowa 5.06.1979. 85-86).

Misjonarska działalność św. Wojciecha stanowi też początek, punkt odniesienia i element identyfikacji niektórych Kościołów lokalnych w Polsce. Na „rodowód” wywodzący się od tego świętego może powoływać się, o czym przypomniał Papież, m.in. diecezja elbląska (JP II, Hom. 1, Elbląg 6.06.1999. 1030), gdańska (JP II, Hom.1, Sopot 5.06.1999.1016; JP II, Przem. 2, Gdańsk 5.06.1999. 1013), krakowska (JP II, Hom. 2, Kraków 15.06.1999.1155), pelplińska (JP II, Hom. 2,6, Pelplin 6.06.1999. 1022; 1026), gnieźnieńska (JP II, Przem. 2, Kraków 17.06.1999. 1191) czy koszalińsko-kołobrzeska (JP II Przem. 2, Koszalin 1.06.1991. 560). Postać św. Wojciecha - wielkiego misjonarza ziem polskich, jego misyjna posługa, stanowią niekwestionowany i ważny punkt odniesienia dla zarania nie tylko Kościoła w Polsce, ale i fundamentu organizacji państwa Piastów (JP II, Przem. 2, Koszalin 1.06.1991. 559-560). 
Nauczanie i świadectwo pozostawione przez św. Wojciecha nadal stanowi fundament misji ewangelizacyjnej w Polsce. Jest, zdaniem Jana Pawła II, w całych dziejach narodu żywotne i życiodajne, jawi się jako źródło dla jedności i duchowej odnowy życia wspólnotowego i indywidualnego Polaków w każdym czasie (JP II, Hom. 5, Poznań 3.06.1997. 922). Misyjne przesłanie pozostawione przez św. Wojciecha ciągle stanowi inspirację dla odnowienia egzystencji społecznej i kościelnej w Polsce. Przykład tego misjonarza od przeszło tysiąca lat mówi też pokoleniom Polaków o potrzebie świadectwa, ofiary i braku miejsca na kompromisy, przypomina o potrzebie wierności Bogu do końca (JP II, Orędzie 3, Częstochowa 4.06.1997. 943-944; JP II, Hom. 4, Elbląg 6.06.1999. 1034; JP II. Hom. 2, Bydgoszcz 7.06.1999. 1039). Jest wreszcie św. Wojciech - jako odrzucany w wielu miejscach misjonarz - wzorem i umocnieniem dla rzesz duchownych i świeckich świadków Ewangelii w polskim kontekście życia Kościoła, wzorem i ikoną polskiego duszpasterstwa. Pozostawiony przez tego misjonarza-męczennika przykład wierności może stawać się aktualny i pouczający także w dobie wielkich wyzwań współczesności i różnorodnych przemian, podczas których Kościół i Ewangelia stają się znakiem sprzeciwu dla wielu osób i środowisk (JP II, Orędzie. 2, Kraków 8.06.1997. 979-980).

W czasie swych pielgrzymek, wśród pionierów Ewangelii na rodzimych ziemiach Jan Paweł II dwukrotnie przywołał również braci-eremitów, pierwszych polskich męczenników: Benedykta, Jana, Mateusza, Izaaka i Krystyna. Papież podkreślił, że ich zachowane w pamięci Kościoła w Polsce męczeństwo należy umieścić na progu millenium chrześcijaństwa na ziemiach polskich (JP II, Hom. 1, Gorzów 2.06.1997.899; JP II. Hom. 2, Bydgoszcz 7.06.1999. 1040).

Analizując nauczanie Jana Pawła II, poświęcone dziełu misyjnemu w Polsce na przełomie pierwszego i drugiego tysiąclecia, a zwłaszcza jego głównemu animatorowi - św. Wojciechowi, można stwierdzić, że owe wysiłki stanowią klucz dla właściwego rozumienia i interpretacji polskiej kultury i losów całego narodu (Zagrodzki 30, 34).

\section{Misje fundamentem zjednoczonej Europy}

Przywołując postać św. Wojciecha, Jan Paweł II nie ograniczał się jedynie do jego misji na terenie Polski. Ukazywał go także jako misjonarza Europy, który jednoczył ją wokół wartości wyrosłych na glebie Ewangelii. Umieszczał go obok wielkich misjonarzy Słowian - Cyryla i Metodego. Wskazywał tym samym, że dzieło misyjne Kościoła, zainicjowane wśród ludów słowiańskich, było czynnikiem budującym i jednoczącym ówczesną Europę. Ukazywał, że 
cała znana nam kultura europejska rodziła się dzięki pracy i świadectwu misjonarzy. Przykład misji wśród Słowian wskazuje na duchowe fundamenty, na których zbudowany jest kontynent europejski, i na źródło, z którego wypływa i wciąż może czerpać kultura tego kontynentu. W 1997 r. w Gnieźnie Jan Paweł II mówił:

To patroni Europy - św. Benedykt oraz święci Cyryl i Metody - oni wszczepili w europejską kulturę prawdę o Bogu i człowieku. To orszak świętych misjonarzy, których dziś przypomina nam św. Wojciech, niósł europejskim ludom nowinę o miłości bliźniego, o miłości nieprzyjaciół nawet - nowinę poświadczoną oddaniem za nich życia. Tą dobrą Nowiną - Ewangelią, żyli w Europie przez kolejne stulecia, aż po dzień dzisiejszy, nasi bracia i siostry. Powtarzały ją mury kościołów, opactw, szpitali i uniwersytetów. Głosiły ją foliały, rzeźby, obrazy, obwieszczały strofy poezji i dzieła kompozytorów. Na Ewangelii kładziono podwaliny duchowej jedności Europy. Od grobu św. Wojciecha pytam więc, czy wolno nam odrzucić prawo chrześcijańskiego życia, które głosi, że tylko ten przynosi owoc obfity, kto obumiera dla wszystkiego, co nie Boże, kto dla dobra braci obumiera, jak ziarno rzucone w ziemię. [...] O taką rzeczywistość zabiegał św. Wojciech, za taką rzeczywistość oddał swoje życie. On też nam dziś przypomina, iż nie można zbudować nowego porządku bez odnowionego człowieka, tego najmocniejszego fundamentu każdego społeczeństwa (JP II, Hom. 5, Gniezno 3.06.1997. 911-912).

Papieskie nauczanie wskazuje jednoznacznie, że u początków cywilizacji europejskiej znajdują się: misje Kościoła, wysiłek i trud rzesz chrześcijańskich misjonarzy. Można stwierdzić, że w ocenie Jana Pawła II misje budowały Europę i tworzyły jej oblicze.

W 1999 r. w polskim parlamencie Jan Paweł II przypominał:

Pielgrzymując po ścieżkach czasu, Kościół właśnie z naszym kontynentem związał swą misję tak ściśle, jak z żadnym innym. Duchowe oblicze Europy kształtowało się dzięki wysiłkowi wielkich misjonarzy i dzięki świadectwu męczenników. Kształtowano je w świątyniach wznoszonych $\mathrm{z}$ wielkim poświęceniem i w ośrodkach życia kontemplacyjnego, kształtowano je oczywiście w humanistycznym przesłaniu uniwersytetów. Kościół, powołany do troski o duchowy wzrost człowieka jako istoty społecznej, wnosił w europejską kulturę jednolity zbiór wartości. [...] Jakże uboga pozostałaby kultura europejska, gdyby zabrakło w niej chrześcijańskich inspiracji! Dlatego Kościół przestrzega przed redukowaniem wizji zjednoczonej Europy wyłącznie do jej aspektów ekonomicznych, politycznych i przed bezkrytycznym stosunkiem do konsumpcyjnego modelu życia (JP II, Przem. 6, Warszawa 11.06.1999. 1085-1086).

Przykład oddanego misji Kościoła życia św. Wojciecha Jan Paweł II ukazuje jako wzorzec harmonijnego, a przez to owocnego jednoczenia rozma- 
itych kultur i tradycji. Jego działalność misjonarska wpisała się w dzieje kilku narodów i służy jako przykład potwierdzający jednoczącą (a nie antagonizującą) rolę posługi misyjnej. Życie i działanie św. Wojciecha, które także dzisiaj może stanowić model pracy misyjnej, symbolizuje duchową jedność Europy. Jego egzystencja i misyjna aktywność świadczą o odnalezieniu prawdziwego fundamentu jedności i współpracy. Misyjne metody św. Wojciecha i całych pokoleń misjonarzy Europy mogą pomóc, według Jana Pawła II, w poszukiwaniu pojednania i jedności w dzisiejszej Europie (JP II, Przem., Gniezno 3.06.1999. 915-916).

\section{Inkulturacja}

Mówiąc o znaczeniu i roli działalności misyjnej Kościoła, Jan Paweł II wskazywał na jej szczególne miejsce w kształtowaniu kultury polskiej i europejskiej przez oddziaływanie wartości ewangelicznych. Papież mówił wprost, że Europa jest miejscem, gdzie Ewangelia, przynajmniej w pewnych okresach, najpełniej i najlepiej zasymilowała się z miejscową kulturą. Można powiedzieć, że to kontynent europejski stał się areną najpełniejszej realizacji tego, co współczesna misjologia nazywa inkulturacją (Crollius 125-134; Różański, Wokót koncepcji inkulturacji 11-52). Problemowi inkulturacji czy ewangelizacji kultury Jan Paweł II poświęcił sporo miejsca podczas swych pielgrzymek do ojczyzny i poddał to zagadnienie wnikliwej analizie, podkreślając, że jest to proces długotrwały, domagający się cierpliwości i nadprzyrodzonego spojrzenia (Zagrodzki 426-437).

Nad znaczeniem inkulturacji Jan Paweł II pochylił się szczególnie wtedy, gdy przemawiał do uczestników kongresu teologów Europy Środkowo-Wschodniej. Na spotkaniu wskazał, iż drogę inkulturacji wybrał przez swoje objawienie sam Bóg. Przyjmując ludzką naturę, Słowo w pewnym sensie nauczyło się być człowiekiem, żeby z kolei uczyć ludzi, jak mają stawać się synami Bożymi. Stąd misjonarze ponosili na przestrzeni stuleci trud poznawania kultury ewangelizowanych ludów, by jak najskuteczniej przekazywać im słowo Boże. Przykładem, do którego odwołał się papież, byli Cyryl i Metody. Dzięki nowatorskiemu modelowi pracy misyjnej, opartej na szacunku i poznaniu kultury ewangelizowanych narodów, stali się oni prekursorami i patronami głoszenia Ewangelii z perspektywy inkulturacji (JP II, Przem. 3, Częstochowa 15.08.1991. 821). Bracia Sołuńscy, głosząc Słowianom prawdę objawioną, świadomie i owocnie praktykowali to, co dzisiaj klasyfikuje się jako inkulturację, czyli głoszenie Ewangelii w konkretnym kontekście kulturowym (Różański, Wokół koncepcji inkulturacji 135-138). Jan Paweł II podkreślał: 
Musimy raz jeszcze zdać sobie sprawę z tej pracy, jaką wykonali święci Cyryl i Metody. Jako Grecy nauczyli się naprzód języka Słowian, aby z kolei w tym języku głosić słowo Bożej ewangelii Słowianom. Po nich uczynili to samo przeliczni misjonarze na różnych kręgach długości i szerokości geograficznej. Wszyscy naprzód stawali się uczniami ludów, które mieli nauczać, aby z kolei móc stać się nauczycielami słowa Bożego w ich języku (JP II, Przem. 3, Częstochowa 15.08.1991. 821).

Oczywiście samo poznanie kultury ewangelizowanych ludów stanowi tylko wstępny etap, pomoc i narzędzie w tym, by Ewangelia mogła zakorzenić się w ludzkiej kulturze, a w konsekwencji ową kulturę udoskonalić. Inkulturację rozumiał papież-misjonarz jako wpisywanie się transcendentnego Słowa Wcielonego w stale zmieniającą się immanencję ludzkiego bytowania. Ewangelizację prowadzoną w duchu inkulturacji Jan Paweł II pojmował jako wpisanie się Boga w historię człowieka, by w ten sposób ludzka historia przybierała kształt historii zbawienia (JP II, Przem. 3, Częstochowa 15.08.1991. 822).

Inkulturacja jako element dzieła misyjnego zakłada zachowanie rodzimych kultur, uwypukla, co w nich wartościowe, jednocześnie pozwalając na zachowanie tożsamości i budowanie jedności Kościoła z różnorodności kultur, języków i odmienności. Umożliwia to zachowanie rozmaitości budującej i ożywiającej Kościół. Owoce i konsekwencje tak rozumianego procesu inkulturacji dostrzegł Jan Paweł II, zwracając się do pielgrzymów z Litwy. Powiedział wówczas:

Żyjecie tutaj na ziemi waszych przodków, związani wspólnotą języka litewskiego, dla którego wielkie zasługi położył biskup Antanas Baranauskas [...]. Jednoczy was i wiąże troska o wiarę, kulturę i zachowanie ojczystych obyczajów w waszych rodzinach i społecznościach parafialnych. W ten sposób dokonuje się ubogacenie całego społeczeństwa, a więc i Polski, której jesteście obywatelami. Taką postawę miałem na myśli, pisząc w encyklice Redemptoris missio: „Chrześcijanin i wspólnoty chrześcijańskie żyją dogłębnie włączeni w życie poszczególnych narodów i są znakiem Ewangelii również w wierności swojej ojczyźnie, swemu narodowi, narodowej kulturze, zawsze jednak w wolności, którą przyniósł Chrystus. Chrześcijaństwo jest otwarte na powszechne braterstwo, gdyż wszyscy ludzie są dziećmi tego samego Ojca i braćmi w Chrystusie (n. 43)" (JP II, Przem. 3, Łomża 5.06.1991. 635).

\section{Misje ad gentes jako istotny element określenia natury Kościoła}

Dotychczasowa analiza misyjnego nauczania Jana Pawła II podczas pielgrzymek do ojczyzny dotyczy głównie jego historycznego aspektu. Przybywa- 
jąc do Polski, wśród zmieniających się uwarunkowań polityczno-społecznych, podkreślał również, że misje ad gentes są okazją do ukazywania natury Kościoła. Jego nauczanie można w całości uważać za wezwanie do nowej ewangelizacji, ale odnajdujemy w nim także wyraźne odniesienia do roli i miejsca misji ad gentes w rozumieniu i życiu Kościoła.

Już w czasie pierwszej pielgrzymki do Polski, w Częstochowie, w trakcie rozważania przed modlitwą Anioł Pański, papież nazwał tę modlitwę ,pierwszą modlitwą misyjną" (JP II, Rozw. Częstochowa 6.06.1979.127). Wskazał, że posłannictwo archanioła Gabriela stanowiło misję zapowiadającą i rozpoczynającą misję samego Jezusa Chrystusa i Jego Kościoła. Słowa tej modlitwy powinny, zdaniem Jana Pawła II, przypominać i uświadamiać wszystkim wierzącym, że są oni członkami wspólnoty posłanej i będącej w stanie misji, a pierwszym i podstawowym zadaniem duchowieństwa i laikatu jest zaangażowane i odpowiedzialne podejmowanie misji Kościoła posłanego do świata. Kościół w Polsce powinien posiadać zatem świadomość misyjną, uzmysłowić sobie w rodzimych realiach uczestniczenie w misji Kościoła powszechnego na całej ziemi (JP II, Rozw. Częstochowa 6.06.1979.127). W tym samym duchu, w czerwcu 1987 r. papież przekonywał:

Kościół cały jest misyjny. Cały i wszędzie! Wy wszyscy, którzy nie podejmujecie posługi na terenach misyjnych - nie zapominajcie, że nasza własna, polska Ojczyzna wciąż potrzebuje nowej ewangelizacji. Podobnie jak cała chrześcijańska Europa. Po setkach lat - i tysiącleciach - wciąż na nowo! Cała Europa stała się kontynentem nowego wielkiego wyzwania dla Ewangelii. I Polska też (JP II, Hom. 7, Warszawa 14.06.1987. 546).

O tym podstawowym i ciągle aktualnym posłaniu wszystkich wiernych, wynikającym z sakramentu chrztu i bierzmowania, Jan Paweł II przypomniał również w 1991 r. w Częstochowie. Uwypuklał wtedy rolę Ducha Świętego, który uzdalnia do odważnego świadectwa dawanego przez wierzących, a to pozwala realizować w każdym czasie misję Kościoła. Wskazywał, że dzięki Niemu dzieje Kościoła są dziejami świadków Jezusa Chrystusa, uobecniających tajemnicę Boga żywego w świecie (JP II, Przem. 5, Częstochowa 15.08.1991. 823).

Oprócz tego głównego i powszechnego wymiaru misyjnej natury Kościoła, dotyczącego wszystkich ochrzczonych, Jan Paweł II wskazał również na specjalne powołanie misyjne. W przywołanym rozważaniu przed modlitwą Anioł Pański z 1979 r. papież wyraził swoją radość z tego powodu, że Kościół w Polsce, mimo iż doświadcza właściwych tamtym czasom przeciwności, nie tylko trwa w swojej misji, ale staje się coraz bardziej Kościołem misjonarskim. Świadomy trudności, na jakie napotykało wówczas posyłanie misjona- 
rzy ad gentes, podkreślił, że wzrasta liczba kapłanów zakonnych i diecezjalnych, sióstr zakonnych, a nawet świeckich wyjeżdżających na misje (JP II, Rozw. Częstochowa 6.06.1979. 127).

W trakcie swego rozważania Jan Paweł II przytoczył również definicję misji ad gentes. Scharakteryzował je jako pracę tam ,gdzie wiara nie jest ugruntowana. Gdzie jeszcze Kościół nie jest ukonstytuowany, gdzie trzeba go tworzyć, gdzie trzeba do Chrystusa przybliżać, nawracać ludzi, pokazywać im drogę". Kończąc rozważanie, zachęcił Kościół w Polsce do trwania w głębokiej świadomości swej misyjnej natury i jednocześnie do stawania się coraz bardziej misjonarskim poprzez gotowość do dzielenia się z innymi Kościołami lokalnymi - „Kościołami na misjach” - swoją obfitością powołań kapłańskich i zakonnych (JP II, Rozw. Częstochowa 6.06.1979. 127-128).

Tego samego dnia, podczas spotkania z kapłanami, papież mówił o swoistej rozterce, jaką przeżywał. Wspominał, że jako biskup Krakowa sam tłumaczył i usprawiedliwiał niewielką ilość misjonarzy z Polski ówczesną trudną sytuacją polityczną w kraju. Jako „głowa” Kościoła powszechnego dostrzega teraz potrzeby całego Kościoła i widzi wyraźnie wielkie ,zapotrzebowanie" na polskich misjonarzy w wielu miejscach w świecie. $Z$ owej zmienionej perspektywy apelował o obudzenie misyjnej świadomości i zaangażowanie Kościoła polskiego w dzieło misji ad gentes (JP II, Przem. 5, Częstochowa 6.06.1979. 122-123). W dalszej części rozważania papież zapewnił o szacunku i uznaniu, z jakimi spotykają się w krajach misyjnych księża pochodzący z Polski. Uwydatnił również konieczność wrażliwości na personalne potrzeby misyjnych Kościołów lokalnych. Zachęcał do rozeznawania powołania misyjnego i do podejmowania pracy misyjnej. Opisywał to powołanie wskazując, że myśl soborowa określa posłannictwo kapłana jako posłannictwo uniwersalne, skierowane zawsze do całego Ludu Bożego. Zatem w każde powołanie kapłańskie, jego zdaniem, wpisane jest także powołanie misyjne. Stąd płynęło pośrednio wezwanie papieża do otwartości na dzieło misyjne Kościoła i do hojnego, kadrowego zaangażowania w nie Kościoła w Polsce (JP II, Przem. 5, Częstochowa 6.06.1979. 123-124).

Podobną myśl, z wyrazami uznania i jednocześnie prośbą o hojność dla dzieła misyjnego, zawarł Jan Paweł II również w słowach skierowanych do sióstr zakonnych w Częstochowie w 1979 r. (JP II, Przem. Częstochowa 5.06.1979. 80-81).

O wielkoduszność i dyspozycyjność dla misji apelował papież podczas poświęcenia budynków seminarium duchownego w Łomży, w 1991 r. Mówił wtedy, że powołania kapłańskie są zawsze probierzem żywotności lokalnego Kościoła, znakiem głębi jego życia duchowego. Zwracał zarazem uwagę na to, iż Kościoły bogate w powołania kapłańskie powinny nie tylko zaspokajać miejscowe potrzeby, ale hojnie posyłać swoich misjonarzy do innych krajów, 
które cierpią z powodu braku powołań (JP II, Przem. 3, Łomża 5.06.1991. 641).

Organiczną jedność powołania kapłańskiego i misyjnego Jan Paweł II uwzględnił również, pielgrzymując w 1987 r. do Polski. W Tarnowie, spotykając się z kapłanami, zakonnikami i zakonnicami, mówił o budującym przykładzie, jaki wielokrotnie dają kapłani na wielu polach swej posługi i realizacji powołania kapłańskiego. Przejawem bogactwa Kościoła w Polsce jest także misyjne zaangażowanie Kościoła tarnowskiego czy, patrząc szerzej, polskiego w dzieło misyjne (JP II, Hom. 9, Tarnów 10.06.1987. 433; JP II, Słowo. Stary Sącz 16.06.1999. 1175).

Swoją wdzięczność i uznanie dla wszystkich polskich misjonarzy wyraził Ojciec Święty podczas pielgrzymki w 1983 r., spotkawszy się z członkami zakonnej rodziny franciszkańskiej. Doceniając oraz uwydatniając wartość ich świadectwa i posługi, prosił zarazem o dalsze zaangażowanie w misje ad gentes duchowieństwa zakonnego, diecezjalnego i wiernych świeckich (JP II, Hom. Niepokalanów 18.06.1983. 252-253). Dał tym samym wyraz swej trosce o ciągłe włączanie się Kościoła w Polsce w dzieło misyjne Kościoła powszechnego.

\section{Organizatorzy dzieła misyjnego Kościoła}

W swoim nauczaniu Jan Paweł II wspominał również osoby szczególnie zasłużone dla organizacji i funkcjonowania struktur misyjnych Kościoła. Prawie zawsze jedynie przywoływał daną postać w kontekście dzieła misyjnego, bez szczegółowego wyliczania jej zasług. Odwołując się do tekstów papieskich, można wskazać cztery ważne dla misyjnego dzieła Kościoła postacie.

Pierwszą z nich jest Paweł Włodkowic (1370-1435). Nie był on misjonarzem, nie był też wprost związany z dziełem misyjnym, ale jego działalność można osadzić w kontekście rozważań misjologicznych. Jan Paweł II wspomina go w refleksji nad źródłem i istotą praw człowieka, a przywołuje, umieszczając jego myśl - podwalinę pod nowożytną teorię praw człowieka - wśród największych osiągnięć naukowych Akademii Krakowskiej, czyli późniejszego Uniwersytetu Jagiellońskiego (JP II, Hom. 3, Oświęcim 7.06.1179. 157; JP II, Hom. 5, Kraków 8.06.1997. 972). W owej perspektywie, uwzględniwszy rolę, jaką odgrywa poznanie praw człowieka i ich powiązanie z dziełem misyjnym (Różański, Misje a promocja ludzka 62-71), trzeba wspomnieć postać tego profesora i rektora krakowskiej uczelni.

Swoją myśl dotyczącą podstawowych praw każdego człowieka i ich rozumienia zaprezentował Paweł Włodkowic w trakcie obrad soboru w Konstancji (1414-1418). Podczas dysput z delegacją krzyżacką bronił tezy, że niedopusz- 
czalne jest zmuszanie pogan do przyjmowania wiary. Wszelkiego rodzaju metody siłowe i narzucanie chrześcijaństwa przemocą uznawał za niewłaściwe i sprzeczne z duchem Ewangelii (Urban 611-614).

Paweł Włodkowic dowodził, odwołując się do Ewangelii i prawa naturalnego, że wszystkich ludzi należy traktować jako osoby, jako jednostki obdarzone świadomością i wolnością. Dlatego nie wolno pogan nawracać siłą, a wojny prowadzone $\mathrm{w}$ imię apostolstwa są niesprawiedliwe. Traktował on wszystkich ludzi, zarówno chrześcijan, jak i pogan, jako podmioty praw. Misjonarze są jednocześnie uprawnieni i zobowiązani do głoszenia wszystkim ludziom Dobrej Nowiny o zbawieniu, ale powinni pamiętać, że prawo naturalne stoi na straży godności każdej osoby ludzkiej. Poganie natomiast są zobowiązani do przyjęcia misjonarzy i umożliwienia im działalności misyjnej, ale nikogo i w żadnych okolicznościach nie można zmuszać do przyjęcia wiary czy chrztu (Rutowski 187-190).

Jan Paweł II przypomniał postać Pawła Włodkowica w nawiązaniu do jego zasług jako klasyka prawa międzynarodowego. Śmiało można go wspominać także w kontekście historii misji i przywoływać jego wkład w dzieło ewangelizacji narodów. Do myśli Włodkowica nawiązywał chociażby hiszpański dominikanin, Franciszek de Vitoria, broniący w 1532 r. praw ludności tubylczej w Ameryce Południowej (Rutowski 194).

Podczas drugiej pielgrzymki do Polski Jan Paweł II wspomniał kardynała Mieczysława Ledóchowskiego, arcybiskupa gnieźnieńsko-poznańskiego, prymasa Polski, zasłużonego dla obrony polskości i wiary w dobie kulturkampfu (JP II, Hom. 7, Poznań 20.06.1983. 303).

Kardynał Mieczysław Ledóchowski żył w latach 1822-1902. W 1841 r. wstąpił do seminarium duchownego prowadzonego przez misjonarzy św. Wincentego a Paulo. Studia ukończył ostatecznie w Rzymie, wieńcząc je doktoratami z teologii i obojga praw (1847) oraz przygotowaniem do pracy w dyplomacji papieskiej. W latach 1852-1866 posługiwał w Lizbonie, Nowej Granadzie i Belgii. W 1866 r. został mianowany arcybiskupem gnieźnieńsko-poznańskim. Udział w obradach Soboru Watykańskiego I, a zwłaszcza użycie tytułu ,prymas Polski” w podpisie pod jego dokumentami, rozpoczął okres konfliktu z władzami pruskimi. Zaostrzył się on jeszcze bardziej w dobie nasilającego się kulturkampfu i zakończył pobytem arcybiskupa Ledóchowskiego w latach 1874-1876 w więzieniu. Po uwolnieniu kardynał Ledóchowski wyjechał do Watykanu. W styczniu 1892 r. został mianowany prefektem Kongregacji Rozkrzewiania Wiary. Funkcję tę pełnił do swej śmierci (Klimkiewicz).

Przygotowaniem do pracy na rzecz misji było sprawowanie urzędu delegata apostolskiego w Nowej Granadzie. Ta jednostka administracyjna obejmowała wtedy swą jurysdykcją Wenezuelę, Ekwador, Peru i Boliwię. Biskup Ledóchowski doświadczył wówczas bezpośredniej konfrontacji z warunkami 
pracy misyjnej. Wykorzystując swoje doświadczenie dyplomatyczne, musiał zmierzyć się z problemem rozdziału Kościoła od państwa w tym rejonie oraz $\mathrm{z}$ uporządkowaniem zagadnienia granic politycznego i socjalnego zaangażowania duchowieństwa. W konsekwencji rewolucji, która wybuchła w Kolumbii w 1860 r., Mieczysław Ledóchowski zmuszony był w 1861 r. opuścić ów kraj (planowano nawet zamach na jego życie), a następnie przez Jamajkę i Kubę powrócić do Rzymu (Jabłoński 209-210).

Jako prefekt Kongregacji, kardynał Ledóchowski podjął próby rozwiązania kwestii rywalizacji o patronat misyjny między Włochami i Francją, co było szczególnie palącym problemem na Wschodzie. Mierzył się również z narastającym konfliktem między Kościołem i państwem we Francji, która znajdowała się wówczas w czołówce zaangażowania misyjnego. Kolonialna rywalizacja w Afryce i nasilające się antagonizmy między Niemcami a Anglią i Francją stanowiły kolejne wyzwanie dla watykańskiej kongregacji, której przewodniczył polski kardynał. Problemy i napięcia pojawiały się również w Stanach Zjednoczonych, gdzie napotkano opór miejscowych biskupów sprzeciwiających się ustanowieniu przedstawicielstwa Watykanu (Klimkiewicz, t. 3. 354-368; Jabłoński 211-213).

Kolejnym problemem, jaki musiała rozwiązać Kongregacja, był status Dzieł Misyjnych, które z inicjatyw prywatnych przekształciły się w prężne organizacje domagające się należnego im miejsca w strukturach Kościoła diecezjalnego i powszechnego. W działalności Dzieła Rozkrzewiania Wiary i Dzieła Dziecięctwa Misyjnego trudności zaczęły generować narastające również na płaszczyźnie wspierania misji nacjonalistyczne roszczenia i tendencje. Te uwarunkowania doprowadziły m.in. do powstania odrębnych struktur owych dzieł w Austrii i Niemczech. Przedmiotem zainteresowania i odpowiedzialności Kongregacji stała się również ewangelizacja Dalekiego Wschodu. Był to teren wymagający ze względu na odległość od Europy, a jeszcze bardziej ze względu na swą odmienność kulturową. Przedmiotem troski kardynała Ledóchowskiego jawiło się więc $\mathrm{w}$ odniesieniu do tych terenów zakładanie i prowadzenie miejscowych seminariów. Współpracownikiem Prefekta Kongregacji był tutaj inny Polak - arcybiskup Michał Władysław Zaleski. Stojąc na czele Kongregacji Rozkrzewiania Wiary, zajmował się także organizacją Kolegium Urbanianum kształcącego kleryków z krajów misyjnych oraz propagowaniem i usprawnieniem funkcjonowania Dzieła Rozkrzewiania Wiary (Klimkiewicz, t. 3. 368-369; Jabłoński 213-214).

Kardynał Mieczysław Ledóchowski jest jedynym do tej pory polskim duchownym stojącym na czele watykańskiej kongregacji odpowiedzialnej za organizację misyjnego dzieła Kościoła. Przywołując tę postać, Jan Paweł II wskazywał na wielkie zasługi, jakie Kościół z Polski wykreślonej z mapy Europy wniósł w tym czasie w działalność misyjną. 
Drugą spokrewnioną zresztą z kardynałem Ledóchowskim osobą, zasłużoną dla dzieła misyjnego w wymiarze Kościoła powszechnego, którą wspomniał Jan Paweł II, była Maria Teresa Ledóchowska (JP II, Hom. 7, Poznań 20.06.1983. 302). Ogłoszona w 1975 r. błogosławioną, starsza siostra św. Urszuli Ledóchowskiej, urodziła się w dniu 29 kwietnia 1863 r. w Loosdorf w Austrii, gdzie jej rodzina osiadła po powstaniu listopadowym. Przebyte choroby na tyle odcisnęły piętno na jej myśleniu i duchowości, że ofiarowała swoje życie Bogu. Pod wpływem lektury broszury kardynała Karola Lavigerie, zaangażowanego na rzecz misji w Afryce, zrezygnowała z dotychczasowego stylu życia i całkowicie poświęciła się sprawie misji afrykańskich. Spod jej pióra wyszedł dramat Zaida Murzynka, wystawiony w Salzburgu i w kilku innych miastach. W 1890 r. zaczęła redagować i wydawać „Echo z Afryki”. Rozpoczęła również wydawanie pisemka misyjnego „Murzynek”, adresowanego do dzieci. W 1894 r. zainicjowała działalność Sodalicji św. Piotra Klawera dla Misji Afrykańskich, przekształconej później w Zgromadzenie Sióstr Misjonarek św. Piotra Klawera. W dniu 9 września 1896 r. Maria Teresa Ledóchowska złożyła śluby zakonne. $Z$ czasem wszystkie swoje działania i wysiłki poświęciła służbie misjom afrykańskim, a szczególnie sprawie walki z niewolnictwem na tym kontynencie. Działalność misyjna bł. Marii Teresy Ledóchowskiej polegała głównie na organizowaniu pomocy materialnej dla misji, na oddanej pracy publicystycznej, tematycznych odczytach oraz budzeniu i wspieraniu powołań misyjnych w Europie. Błogosławiona Maria Teresa Ledóchowska zmarła w dniu 6 lipca 1922 r. w Rzymie. Przypisuje się jej zaszczytny przydomek: Matka Afryki, choć nigdy nie wyjechała na misje. W Kościele w Polsce jest patronką dzieł misyjnych (Krzymkowska; Nowak; Molinari; Chadzińska).

Maria Teresa Ledóchowska ożywiła misyjnego ducha Europy, odkryła nowe drogi współpracy misyjnej, angażując w nie rzesze wierzących. Charakteryzując misyjne zaangażowanie Marii Teresy Ledóchowskiej, należy podkreślić jego uniwersalność. Matka Afryki zwracała się w swej akcji misyjnej do wszystkich ochrzczonych, wyprzedzając pod tym względem orzeczenia Soboru Watykańskiego II. Potrafiła także szanować misjonarzy i nawiązywać z nimi kontakt bez względu na ich przynależność narodową czy zakonną. Ukazała sobą wielkie zaangażowanie na rzecz misji i wielką pracę $\mathrm{w}$ tej dziedzinie, nigdy nie będąc na misjach. Była aktywną organizatorką zaplecza misyjnego, zatroskaną o wszystko, co misjom i misjonarzom niezbędne czy potrzebne w ich pracy. Rysem charakterystycznym jej ducha misyjnego była również kreatywność i wszechstronność działań na rzecz misji: stworzenie instytutu misyjnego, podróże misyjne, zaangażowanie współpracowników świeckich, aktywność publicystyczna i zespolenie z pomocą materialną krucjaty modlitewnej w intencji nawrócenia kontynentu afrykańskiego (Dębska 33-40). 
Podczas pierwszej pielgrzymki do ojczyzny Jan Paweł II wspomniał w Częstochowie postać wielce zasłużoną dla organizacji działalności misyjnej w Kościele polskim po drugiej wojnie światowej, a mowa tutaj o płockim biskupie pomocniczym Janie Wosińskim.

Biskup Jan Wosiński urodził się w dniu 15 maja 1914 r. W latach 19281933 uczył się w płockim Niższym Seminarium Duchownym. Po zdaniu matury rozpoczął studia w Wyższym Seminarium Duchownym w Płocku. W dniu 18 czerwca 1939 r. otrzymał święcenia kapłańskie. Od sierpnia 1939 r. do kwietnia 1942 r. pracował jako wikariusz w Pułtusku. Od 1943 r. przebywał w Warszawie, gdzie pełnił funkcję kapelana pomocniczego w Zakładzie Wychowawczym prowadzonym przez urszulanki szare. W tym czasie angażował się także $\mathrm{w}$ pracę duszpasterską wśród podziemnych organizacji zbrojnych i patriotycznych w okupowanej stolicy. Tam też przeżył czas Powstania Warszawskiego. Po wojnie pracował w Pułtusku i Sierpcu. W dniu 20 listopada 1961 r. został mianowany biskupem pomocniczym w Płocku. Po śmierci biskupa Tadeusza Zakrzewskiego pełnił do 1964 r. urząd administratora apostolskiego w diecezji płockiej, następnie w latach 1964-1991 był biskupem pomocniczym w Płocku. Poza posługą duszpasterską w diecezji biskup Wosiński wygłosił około 120 serii rekolekcji, a także wiele konferencji i referatów poświęconych najczęściej tematyce misyjnej i ascetycznej. Zmarł w dniu 19 lipca 1996 r. W pamięci duchowieństwa diecezji zapisał się jako profesor, ojciec duchowny i biskup-misjonarz (Kisiel; Grzybowski).

Jan Paweł II mówił:

Kiedy byłem jeszcze biskupem w Polsce, jako metropolita krakowski, w ciągu roku miałem co najmniej kilkadziesiąt odwiedzin z różnych krajów świata, z różnych kontynentów, nawet z Europy, w poszukiwaniu kapłanów do pracy duszpasterskiej. I trzeba było nieraz tłumaczyć rozmówcom i wymawiać się, „zwalać" wszystko na księdza biskupa Wosińskiego, że to on rozdziela, bo nie można działać w sposób bezładny, musimy mieć jakiś program, jakąś dystrybucję tych sił misyjnych, którymi służymy i służyć pragniemy Kościołowi (JP II, Przem. 5, Częstochowa 6.06.1979. 123).

Owe kilka zdań doskonale streszczało i charakteryzowało oddaną, wieloletnią i owocną pracę biskupa Wosińskiego, skupioną na organizowaniu zaplecza misyjnego w Polsce. Swą posługę na rzecz misji na szczeblu krajowym rozpoczął on w dniu 5 sierpnia 1963 r., gdy został mianowany Przewodniczącym Krajowym Papieskiej Unii Misyjnej. Od 1970 r. biskup Wosiński pełnił także funkcję Dyrektora Krajowego reaktywowanych wówczas w Polsce: Papieskiego Dzieła Rozkrzewiania Wiary i Papieskiego Dzieła św. Piotra Apostoła. Dzieło animacji i przewodniczenia PDM w Polsce zakończył w dniu 24 wrze- 
śnia 1985 r. W ciągu przeszło dwudziestu lat pracy na czele PDM w Polsce zmagał się z brakiem przychylności władz państwowych dla misyjnego dzieła Kościoła. Zajmował się również budzeniem i pogłębianiem świadomości misyjnej wśród duchowieństwa. W tym celu organizował i przewodniczył spotkaniom diecezjalnych dyrektorów dzieł misyjnych i zakonnych promotorów misji. $\mathrm{Z}$ wielkim poświęceniem budował zręby instytucji misyjnych w Polsce, formował animatorów duszpasterstwa misyjnego, opracowywał dokumenty i programy służące animacji misyjnej na szczeblu krajowym i diecezjalnym. Z jego inicjatywy odbyło się w latach 1968-1975 szesnaście serii rekolekcji misyjnych dla kapłanów, którym przewodniczył, głosząc słowo Boże, biskup Wosiński. W celu formacji misyjnej alumnów seminariów duchownych zainicjował coroczne sympozja misyjne dla kleryków (Adamiak 306-341).

Biskup Jan Wosiński należał również, od początku jej istnienia (1967), do Komisji Misyjnej Episkopatu Polski. Po śmierci jej pierwszego przewodniczącego (biskupa Kazimierza Kowalskiego) zostały wybrany w dniu 28 czerwca 1972 r. na to stanowisko i przewodził pracom owego gremium do dnia 27 marca 1984 r. Do zadań przewodniczącego Komisji Misyjnej KEP należało m.in. budzenie świadomości misyjnej wśród biskupów i organizowanie wyjazdów misyjnych księży diecezjalnych. Tę drugą sprawę regulowała specjalna instrukcja przyjęta w dniu 24 stycznia 1974 r. Ważną sprawą było także określenie zakresu współpracy między strukturami episkopatu a PDM. W ich strukturach biskup Wosiński prezentował swoją myśl misyjną, dzielił się nią oraz wcielał w życie konkretne rozwiązania i formy pracy. Jego misyjne doświadczenie i refleksje znaleźć można w niezbyt licznych, ale dostępnych, wystąpieniach radiowych i opublikowanych artykułach. Był otwarty na innowacje w pracy na rzecz misji. Bardzo sobie cenił osobiste spotkania z misjonarzami. Można rzec, że był pionierem idei misyjnej w polskim episkopacie i niezmordowanie przecierał szlak dla idei misyjnej w Polsce w drugiej połowie XX w. (Adamiak 341-362).

Przywołane przez Jana Pawła II postacie animatorów i organizatorów pracy misyjnej dowodzą, że idea misyjna znajdowała w Polsce swoich propagatorów. W zależności od kontekstu historycznego, w którym żyli, dali oni ważny impuls dla misyjnej działalności Kościoła w wymiarze powszechnym bądź lokalnym. Stanowili też wzór i zaproszenie do misyjnego zaangażowania laikatu i duchowieństwa w Kościele polskim.

\section{Postacie polskich misjonarzy}

W swojej misyjnej katechezie do Polaków Jan Paweł II przywołał również postacie kilku misjonarzy, którzy poświęcili się pracy misyjnej. Jednym 
z nich jest jezuita Jan Beyzym, którego Jan Paweł II wyniósł do chwały ołtarzy w dniu 18 sierpnia $2002 \mathrm{r}$.

Jan Beyzym przyszedł na świat w Beyzymach Wielkich (Wołyń) w dniu 15 maja 1850 r. Pochodził z patriotycznej rodziny, która odczuła skutki powstania styczniowego. W grudniu 1872 r. wstąpił do zakonu jezuitów w Starej Wsi. Zakończywszy formację zakonną, przyjął w Krakowie w dniu 26 lipca 1881 r. święcenia kapłańskie. Po złożeniu w 1886 r. ostatnich ślubów zakonnych, został wysłany do konwiktu w Chyrowie, gdzie przez dziesięć lat był wychowawcą młodzieży. Przełożeni zakonni, widząc jego pedagogiczne talenty, mianowali go wychowawcą w konwikcie, a także prefektem szkolnej infirmerii. W tę ostatnią działalność angażował się z wielkim oddaniem. Mimo tak zajmującej posługi o. Beyzym poszukiwał i pragnął czegoś więcej. Chciał całkowicie i bez reszty zaangażować się w pomoc ludziom najbardziej nieszczęśliwym, pogardzanym i odrzucanym, najbiedniejszym z biednych. W wieku 48 lat rozpoznał u siebie powołanie misyjne i zdecydował się na wyjazd do pracy wśród trędowatych. W dniu 17 października 1898 r. opuścił Polskę i przez Francję udał się na Madagaskar. Już pierwszy kontakt z tamtejszą rzeczywistością był przytłaczający. Chorzy, skupieni w dużych grupach zamieszkiwali walące się baraki, pozbawione podłóg i najpotrzebniejszych nawet sprzętów. Nie chroniły one wystarczająco przed zimnem i deszczem. Działo się to za przyzwoleniem zarówno władz cywilnych, jak i większości społeczeństwa, odmawiających chorym prawa do godziwej egzystencji. W lutym 1899 r. o. Beyzym zamieszkał w skromnym domku obok państwowego leprozorium w Ambahiwaruka. Od pierwszych chwil pobytu na Madagaskarze angażował się w pomoc dla chorych: zbierał jałmużnę, pielęgnował. W historii misji na Madagaskarze o. Beyzym był pierwszym księdzem, który zamieszkał wśród trędowatych, towarzyszył ich niedoli i obsługiwał, nie zważając na to, że może się zarazić. Został zapamiętany jako ten, który traktował trędowatych na równi z innymi ludźmi, udowadniając, że dla niego liczył się przede wszystkim człowiek. $Z$ czasem zrodziło się w jego sercu pragnienie utworzenia własnego szpitala, w którym trędowaci mogliby znaleźć schronienie i potrzebną im opiekę. Z prośbą o pomoc w realizacji tego dzieła zwrócił się do społeczeństwa polskiego. W tym celu zaczął publikować w miesięczniku „Misje Katolickie” swoje listy. Tą drogą pragnął wzbudzić szerokie zainteresowanie sprawami misji, a szczególnie losem ludzi trędowatych i warunkami, w jakich żyli. Wsparcie finansowe i materialne w postaci paczek z rzeczami potrzebnymi chorym oraz z naczyniami i szatami liturgicznymi przesyłała mu m.in. Maria Teresa Ledóchowska. Ponadto publikowała ona w czasopiśmie „Echo z Afryki” jego listy i apele. Ojciec Beyzym był przekonany, że Polska, mimo iż nieobecna $w$ tym czasie na mapie świata, pomoże mu zbudować miejsce godne ludzi cierpiących. Choć był świadomy sytuacji w kraju, odwoływał 
się do serc dobrych i miłosiernych, licząc na skuteczną pomoc. Znacznego wsparcia i pomocy finansowej udzieliła także Polonia, głównie amerykańska.

Dzięki determinacji i oddaniu o. Beyzyma oraz ofiarnej pomocy rodaków udało się wybudować pierwszy z prawdziwego zdarzenia szpital dla trędowatych w Ambatuwuri, w pobliżu Marana. Szpital ostatecznie ukończono w 1911 r.; mógł pomieścić 250 pacjentów. W swoim ośrodku o. Beyzym prowadził również systematyczne nauczanie religijno-moralne, organizował rekolekcje i nabożeństwa, udzielał sakramentów. Poza okazywaniem miłosierdzia w uczynkach względem ciała, o. Beyzym był też zatroskany o dusze ludzkie i zbawienie każdego chorego. Wycieńczony pracą i surowym trybem życia, zmarł w dniu 2 października 1912 r. (Tomaszewski).

W trakcie homilii podczas Mszy Świętej beatyfikacyjnej Jan Paweł II powiedział:

Pragnienie niesienia miłosierdzia najbardziej potrzebującym zaprowadziło błogosławionego Jana Beyzyma - jezuitę, wielkiego misjonarza - na daleki Madagaskar, gdzie z miłości do Chrystusa poświęcił swoje życie trędowatym. Cieszę się, że ten duch solidarności w miłosierdziu wciąż panuje w polskim Kościele, czego dowodem jest wiele dzieł pomocy społecznościom dotkniętym przez klęski żywiołowe w różnych regionach świata czy też niedawna inicjatywa skupu nadwyżek zboża, aby można było przekazać je głodującym w Afryce. Mam nadzieję, że ta szlachetna idea doczeka się realizacji. W duchu miłosierdzia nieustannie wspierajcie misjonarzy pomocą i modlitwą (JP II, Hom. Kraków 18.08.2002. 1214).

Beatyfikowany misjonarz o. Jan Beyzym jest przedstawiony przez Jana Pawła II jako wzorzec miłości cierpliwej i ofiarnej. Jest żywym dowodem na to, jak przez posługę misyjną można okazać miłosierdzie tym, którzy na nie czekają. W owej krótkiej wypowiedzi papież przypomina również, że działalność misjonarzy, a także każda forma wsparcia dla misyjnego dzieła Kościoła, zasługuje na miano czynu miłosierdzia i jest przejawem jego wyobraźni.

Kolejną postacią zasłużoną i ważną dla refleksji misyjnej był św. Maksymilian Maria Kolbe. Dwudziestosześciokrotnie podczas swoich pielgrzymek Jan Paweł II przywoływał również przykład jego życia i dzieła. Czynił to, ukazując w swym nauczaniu najczęściej męczeńską śmierć świętego w obozie zagłady w Oświęcimiu, stanowiącą zwieńczenie procesu jego dojrzewania do świętości. Wspominając tę postać, warto podkreślić, że o. Maksymilian Maria Kolbe odkrył u siebie powołanie misyjne i przez kilka lat niezwykle ofiarnie i owocnie pracował jako misjonarz w Japonii. Zamierzał utworzyć placówkę misyjną w Chinach. Na początku 1930 r. udał się jednak do Japonii i osiadł w Nagasaki. W kwietniu 1931 r. pracowało w Japonii dwunastu franciszkanów. Rozpoczął tam wydawanie „Rycerza Niepokalanej”. Pierwszy numer 
ukazał się w nakładzie 10 tysięcy egzemplarzy. Ojciec Maksymilian wykładał także w tamtejszym seminarium duchownym. W Nagasaki, na zboczu góry Hikosan, założył japoński Niepokalanów. Po sześciu latach pracy misyjnej, w 1936 r. powrócił do Polski, nie przestając jednak interesować się założoną przez siebie misją i jej wspierać (Kluz 91-114; 123-125; Sotowski 158-211).

Przywoławszy misyjny epizod z biografii św. Maksymiliana warto wskazać, że pozostawił on, znany i dzisiaj, pewien model duchowości misyjnej. Zwrócił na to uwagę m.in. biskup Jan Wosiński. Charakteryzując misyjny okres w życiu świętego, zauważył, że pragnienie posługi misjonarskiej zrodziło się u św. Maksymiliana w czasie jego duchowego dojrzewania i rozwoju. Ojciec Maksymilian potrafił zdobywać i wychowywać oddanych sobie współpracowników. Doskonale posługiwał się w pracy misyjnej metodą dialogu. W swej posłudze misjonarskiej potrafił stworzyć i wykorzystać misyjne zaplecze w kraju. W symbiozie ośrodka niepokalanowskiego i japońskiego, w praktyce ukazał naukę o wzajemnym ożywianiu i ubogacaniu się Kościołów powiązanych ze sobą w dziele misyjnym. Ojciec Maksymilian Maria Kolbe był wielkim apostołem misyjnego dzieła Kościoła w Polsce międzywojennej. Jego duchowość misyjna była zintegrowana z duchowością franciszkańską, dojrzałą duchowością maryjną, jedną i drugą podporządkowaną ostatecznie duchowości chrystologicznej. Misyjna działalność św. Maksymiliana, której nie można pomijać w jego życiorysie, także może stanowić źródło inspiracji dla dzisiejszej odnowy ewangelizacyjnej misji Kościoła (Wosiński; Wysocki).

Przywołując misyjne zaangażowanie Kościoła w Polsce, uwidaczniające się w posyłaniu misjonarzy ad gentes, Jan Paweł II w 1999 r. wskazał na wkład diecezji tarnowskiego w to dzieło. Przodowała ona w statystykach misyjnych, a niektórzy posłani z niej misjonarze swe świadectwo przypieczętowali męczeńską krwią. Jan Paweł II mówił:

Cieszę się, że duch apostolski świętych i błogosławionych żywy jest stale w Kościele tarnowskim. Już od 25 lat wasza diecezja prowadzi swe dzieło misyjne w Kongo-Brazzaville. Wielu pochodzących z tej diecezji, duchownych i świeckich uczestniczy w działalności misyjnej kościoła w różnych częściach świata. Spośród nich trzy osoby przypieczętowały misyjne powołanie ofiarą życia. Ojciec Zbigniew Strzałkowski, franciszkanin konwentualny, ksiądz Jan Czuba, kapłan diecezjalny i kleryk Robert Gucwa. Proszę Boga, aby ta misyjna służba i posiew krwi wydały obfite owoce (JP II, Słowo. Stary Sącz 16.06.1999. 1175).

Warto, choćby pokrótce, przybliżyć postacie wspomnianych przez papieża misjonarzy-męczenników.

Ojciec Zbigniew Strzałkowski urodził się w dniu 3 lipca 1958 r. w Tarnowie. W listopadzie 1988 r. przybył do Peru i zamieszkał w Limie. Po odbyciu 
stażu duszpasterskiego, w dniu 30 sierpnia 1989 r. wraz z ojcem Michałem Tomaszkiem przejął parafię w Pariacoto. Obejmowała ona 70 wiosek. Misjonarze katechizowali powierzonych ich trosce mieszkańców, organizowali szkolenia o zakładaniu sieci wody pitnej, pomagali materialnie w parafii. W dniu 9 sierpnia $1991 \mathrm{r}$. ojcowie Zbigniew i Michał zostali porwani, a następnie zamordowani przez lewicowe ugrupowanie „Świetlisty Szlak”. Ich ciała pochowano w sarkofagach w kościele parafialnym w Pariacoto. Rząd peruwiański przyznał im pośmiertnie najwyższe odznaczenie państwowe: Wielki Order Oficerski „El Sol del Peru (Polscy misjonarze w świecie. 50 lat od Dekretu soborowego „Ad gentes”. t. 2. 224). W dniu 5 grudnia 2015 r. miała miejsce beatyfikacja obu męczenników.

Ksiądz Jan Czuba poniósł śmierć na placówce misyjnej na kontynencie afrykańskim, w Republice Konga. Urodził się w dniu 7 czerwca 1959 r. w Pilznie. Święcenia kapłańskie przyjął w dniu 27 maja 1984 r. Posługę misyjną rozpoczął w 1989 r. Pracował najpierw w Mindouli, a w 1992 r. został proboszczem parafii pw. św. Tomasza Apostoła w Loulombo. Udało mu się wybudować aptekę i dom dla posługujących w parafii sióstr. W planach miał również budowę szpitala i kościoła. Pracy misyjnej na rzecz 36 wiosek nie przerwał nawet po wybuchu wojny domowej w kraju. Choć wiedział, że na placówce misyjnej nie jest bezpieczny, to jednak pozostał na niej wraz ze swymi parafianami. Dwa dni przed śmiercią, w liście do przyjaciela jednoznacznie zadeklarował, że mimo zagrożenia pozostaje na miejscu do końca. Został zastrzelony przez rebeliantów w dniu 27 października 1997 r. Jego grób znajduje się w Loulombo (Polscy misjonarze w świecie. 50 lat od Dekretu soborowego „Ad gentes”. t. 1, 74-75).

Trzecim wspomnianym przez papieża misjonarzem-męczennikiem był kleryk Robert Gucwa. Urodził się w dniu 24 marca 1969 r. w Tarnowie. Przynależał do Stowarzyszenia Misji Afrykańskich. W ramach formacji seminaryjnej i misyjnej przebywał od 1991 r. w Togo, Ghanie i Beninie. W 1994 r. zaczął studiować teologię w Republice Środkowej Afryki, w domu formacyjnym w Bangui. Zabito go podczas napadu na placówkę w dniu 15 listopada 1994 r. (Polscy misjonarze w świecie. 50 lat od Dekretu soborowego „Ad gentes”. t. 1, 114).

Przywołane przez Jana Pawła II postacie misjonarzy przybliżają zaangażowanie i misyjną wrażliwość Kościoła w Polsce. Potwierdzają prawdę, że w każdym okresie historii naszej ojczyzny obecni byli misjonarze, którzy nieśli Ewangelię ,aż po krańce ziemi”.

Umacniając wiarę swoich braci i sióstr podczas pielgrzymek do Polski, Jan Paweł II poruszył także temat misji. Papież zauważył i wskazał na przykładzie historii swego narodu na to, że misje budowały polską państwowość i kształtowały polską kulturę. Apelował, by ten proces dostrzec w historii całej 
Europy i uznać w ewangelizacji czynnik budujący i określający jej prawdziwą tożsamość. Uwypuklił też prawdę o tym, że misje pomagają przepajać ludzką kulturę elementem nadprzyrodzonym, który ją uszlachetnia i wynosi. Przypominał prawdę o misyjnej naturze Kościoła i misyjnym powołaniu wszystkich jego członków. Odpowiedzialność i współpraca w dziele misyjnym to dla Jana Pawła II jedna z form „wyobraźni miłosierdzia”. Apelując do rodaków o misyjną hojność i zaangażowanie, wskazał również na postacie, które zapisały się w animacji dzieła misyjnego w Kościele polskim i powszechnym. W swoim nauczaniu w Polsce przypomniał więc o misyjnym zadaniu wspólnoty Kościoła i każdego wiernego.

\section{MISSIONARY TEACHING OF JOHN PAUL II DURING HIS PILGRIMAGE TO POLAND}

\section{Summary}

During his pilgrimages to his homeland, John Paul II was teaching his countrymen about the problems specific to the Church in Poland, but also to the whole Church. One of these themes was the missions ad gentes. The Pope noticed and pointed out on the example of the history of his nation that missions built Polish statehood and shaped Polish culture. He called for this process to be recognized in the history of Europe as a whole and to recognize in evangelization the factor that builds and defines its true identity. He showed that missions help imbue human culture with a supernatural element. He recalled the truth about the missionary nature of the Church and the missionary vocation of all its members. Responsibility and cooperation in the missionary work was for John Paul II one of the forms of the "imagination of mercy." Appealing to his countrymen for missionary generosity and commitment, he also pointed to the figures who were involved in the animation of the missionary work in the Polish and universal Church. In his teaching in Poland, he recalled the missionary task of the Church community and of each and every faithful.

Keywords: pilgrimages of John Paul II; St. Wojciech, missions among the Slavs; missions ad gentes; inculturation; Polish missionaries

Słowa kluczowe: pielgrzymki Jana Pawła II; św. Wojciech; misje wśród Słowian; misje ad gentes; inkulturacja; polscy misjonarze 


\section{Wykaz skrótów}

JP II, Hom. Bydgoszcz 7.06.1999 - Jan Paweł II, Homilia w czasie Mszy św., Bydgoszcz, 7 czerwca 1999. Jan Paweł II. Pielgrzymki do Ojczyzny. Kraków: Znak, 2012. 1038-1044.

JP II, Hom. Elbląg 6.06.1999 - Jan Paweł II, Homilia w czasie nabożeństwa czerwcowego. Elbląg, 6 czerwca 1999. Jan Paweł II. Pielgrzymki do Ojczyzny. Kraków: Znak, 2012. 1030-1035.

JP II, Hom. Gniezno 3.06.1979 - Jan Paweł II. Homilia w czasie Mszy św. odprawionej na Wzgórzu Lecha, Gniezno 3 czerwca 1979. Jan Paweł II. Pielgrzymki do Ojczyzny. Kraków: Znak, 2012. 33-39.

JP II, Hom. Gniezno 3.06.1997 - Jan Paweł II. Homilia w czasie Mszy św. odprawionej na placu przed katedrą. Gniezno 3 czerwca 1997. Jan Paweł II. Pielgrzymki do Ojczyzny. Kraków: Znak, 2012. 907-914

JP II, Hom. Gorzów 2.06.1997 - Jan Paweł II. Homilia w czasie liturgii słowa odprawionej przed kościołem Braci Polskich Męczenników. Gorzów Wielkopolski, 2 czerwca 1997. Jan Paweł II. Pielgrzymki do Ojczyzny. Kraków: Znak, 2012. 899-905.

JP II, Hom. Kraków 8.06.1997 - Jan Paweł II, Homilia wygłoszona w czasie Mszy św. kanonizacyjnej bł. Królowej Jadwigi, Kraków, 8 czerwca 1997. Jan Paweł II. Pielgrzymki do Ojczyzny. Kraków: Znak, 2012. 968-974.

JP II, Hom. Kraków 15.06.1999 - Jan Paweł II. Homilia w czasie Mszy św. odprawionej na Błoniach, Kraków 15 czerwca 1999. Jan Paweł II. Pielgrzymki do Ojczyzny. Kraków: Znak, 2012. 1154-1163.

JP II, Hom. Kraków 18.08.2002 - Jan Paweł II, Homilia w czasie Mszy św. beatyfikacyjnej abpa Zygmunta Szczęsnego Felińskiego, o. Jana Beyzyma, Jana Balickiego i s. Sancji Janiny Szymkowiak, odprawionej na Błoniach. Kraków 18 sierpnia 2002. Jan Paweł II. Pielgrzymki do Ojczyzny. Kraków: Znak, 2012. 1211-1215.

JP II, Hom. Niepokalanów 18.06.1983 - Jan Paweł II, Słowo na zakończenie Mszy św., Niepokalanów, 18 czerwca 1983. Jan Paweł II. Pielgrzymki do Ojczyzny. Kraków: Znak, 2012. 246-253.

JP II, Hom. Oświęcim 7.06.1179 - Jan Paweł II. Homilia w czasie Mszy św. odprawionej na terenie byłego obozu koncentracyjnego. Oświęcim-Brzezinka, 7 czerwca 1979. Jan Paweł II. Pielgrzymki do Ojczyzny. Kraków: Znak, 2012. 154-158.

JP II, Hom. Pelplin 6.06.1999 - Jan Paweł II. Homilia w czasie Mszy św. odprawionej na Biskupiej Górze, Pelplin, 6 czerwca 1999. Jan Paweł II. Pielgrzymki do Ojczyzny. Kraków: Znak, 2012. 1022-1028.

JP II, Hom. Poznań 3.06.1997 - Jan Paweł II, Homilia w czasie liturgii słowa skierowana do młodzieży zgromadzonej na placu Mickiewicza, Poznań, 3 czerwca 1997. Jan Paweł II. Pielgrzymki do Ojczyzny. Kraków: Znak, 2012. 917-924.

JP II, Hom. Poznań 20.06.1983 - Jan Paweł II, Homilia w czasie Mszy św. beatyfikacyjnej matki Urszuli Ledóchowskiej. Poznań, 20 czerwca 1983. Jan Paweł II. Pielgrzymki do Ojczyzny. Kraków: Znak, 2012. 299-306.

JP II, Hom. Sopot 5.06.1999 - Jan Paweł II, Homilia w czasie Mszy św. Sopot, 5 czerwca 1999. Jan Paweł II. Pielgrzymki do Ojczyzny. Kraków: Znak, 2012. 1016-1021.

JP II, Hom. Tarnów 10.06.1987 - Jan Paweł II. Homilia w czasie nieszporów eucharystycznych skierowana do księży, zakonników i zakonnic. Tarnów, 10 czerwca 1987. Jan Paweł II. Pielgrzymki do Ojczyzny. Kraków: Znak, 2012. 429-433.

JP II, Hom. Warszawa 14.06.1987 - Jan Paweł II. Homilia w czasie Mszy św. beatyfikacyjnej biskupa Michała Kozala, odprawionej na placu defilad na zakończenie II Krajowego Kongresu Eucharystycznego. Warszawa 14 czerwca 1987. Jan Paweł II. Pielgrzymki do Ojczyzny. Kraków: Znak, 2012. 541-546.

JP II, Orędzie. Częstochowa 4.06.1997 - Jan Paweł II. Orędzie do osób konsekrowanych, Częstochowa, 4 czerwca 1997 (niewygłoszone). Jan Paweł II. Pielgrzymki do Ojczyzny. Kraków: Znak, 2012. 941-947. 
JP II, Orędzie. Kraków 8.06.1997 - Jan Paweł II, Orędzie do Konferencji Episkopatu Polski, Kraków, 8 czerwca 1997 (niewygłoszone). Jan Paweł II. Pielgrzymki do Ojczyzny. Kraków: Znak, 2012. 978-982.

JP II, Przem. Częstochowa 5.06.1979 - Jan Paweł II. Przemówienie do Konferencji Episkopatu Polski. Częstochowa, 5 czerwca 1979. Jan Paweł II. Pielgrzymki do Ojczyzny. Kraków: Znak, 2012. 82-95.

JP II, Przem. Częstochowa 5.06.1979 - Jan Paweł II, Przemówienie do wyższych przełożonych żeńskich zakonów i zgromadzeń zakonnych, Częstochowa, 5 czerwca 1979. Jan Paweł II. Pielgrzymki do Ojczyzny. Kraków: Znak, 2012. 78-81.

JP II, Przem. Częstochowa 6.06.1979 - Jan Paweł II, Przemówienie do księży zgromadzonych w katedrze. Częstochowa, 6 czerwca 1979. Jan Paweł II. Pielgrzymki do Ojczyzny. Kraków: Znak, 2012. 117-124.

JP II, Przem. Częstochowa 15.08.1991 - Jan Paweł II. Przemówienie do uczestników Kongresu Teologów Europy Środkowowschodniej. Częstochowa, 15 sierpnia 1991. Jan Paweł II. Pielgrzymki do Ojczyzny. Kraków: Znak, 2012. 820-826.

JP II, Przem. Gdańsk 5.06.1999 - Jan Paweł II. Przemówienie powitalne na lotnisku Rębiechowo. Gdańsk 5 czerwca 1999. Jan Paweł II. Pielgrzymki do Ojczyzny. Kraków: Znak, 2012. 1013-1015.

JP II, Przem. Gniezno 3.06.1999 - Jan Paweł II, Przemówienie do prezydentów siedmiu państw Europy Środkowej, Gniezno, 3 czerwca 1997. Jan Paweł II. Pielgrzymki do Ojczyzny. Kraków: Znak, 2012. 915-916.

JP II, Przem. Koszalin 1.06.1991 - Jan Paweł II, Przemówienie powitalne na lotnisku w Zegrzu Pomorskim, Koszalin, 1 czerwca 1991. Jan Paweł II. Pielgrzymki do Ojczyzny. Kraków: Znak, 2012. 559-561.

JP II, Przem. Kraków 17.06.1999 - Jan Paweł II. Przemówienie pożegnalne na lotnisku w Balicach, Kraków 17 czerwca 1999. Jan Paweł II. Pielgrzymki do Ojczyzny. Kraków: Znak, 2012. 1191-1195.

JP II, Przem. Łomża, 5.06.1991 - Jan Paweł II. Przemówienie do pielgrzymów litewskich, Łomża, 5 czerwca 1991. Jan Paweł II. Pielgrzymki do Ojczyzny. Kraków: Znak, 2012. 635-638.

JP II. Przem. Łomża 5.06.1991 - Jan Paweł II, Przemówienie wygłoszone z okazji ceremonii poświęcenia nowej części budynku Wyższego Seminarium Duchownego diecezji łomżyńskiej. Łomża, 5 czerwca 1991. Jan Paweł II. Pielgrzymki do Ojczyzny. Kraków: Znak, 2012. 639-641.

JP II, Przem. Warszawa 11. 6.1999 - Jan Paweł II, Przemówienie wygłoszone w Parlamencie, Warszawa, 11 czerwca 1999. Jan Paweł II. Pielgrzymki do Ojczyzny. Kraków: Znak, 2012. 1080-1087.

JP II, Rozw. Częstochowa 6.06.1979 - Jan Paweł II, Rozważanie przed modlitwą „Anioł Pański”, Częstochowa, 6 czerwca 1979. Jan Paweł II. Pielgrzymki do Ojczyzny. Kraków: Znak, 2012. 127-128.

JP II. Słowo. Stary Sącz 16.06.1999 - Jan Paweł II, Homilia w czasie Mszy św. kanonizacyjnej bł. Kingi, Stary Sącz, 16 czerwca 1999. Jan Paweł II. Pielgrzymki do Ojczyzny. Kraków: Znak, 2012. 1169-1177.

\section{BIBLIOGRAFIA}

Adamiak, Grzegorz. Recepcja idei misyjnej w diecezji płockiej w latach 1908-2015. Warszawa: Instytut Papieża Jana Pawła II, 2020.

Chadzińska, Agnieszka. „Matka Afryki - bł. Maria Teresa Ledóchowska.” Dostęp 20 lutego 2020. $<$ https://www.niedziela.pl/artykul/773/Matka-Afryki-8211-bl-Maria-Teresa $>$

Crollius, Arji Roest. „Inkulturacja.” Kościół misyjny. Podstawowe studium misjologii. Red. Sebastian Karotempler. Warszawa: Missio-Polonia, 1997. 125-134.

Dębska, Janina. „W służbie misji Maria Teresa Ledóchowska i misje.” W nurcie zagadnień posoborowych. Red. Bogdan Bejze. T. 9. Warszawa: Wydawnictwo Sióstr Loretanek, 1977. 33-40.

Górski, Jan. Nowy paradygmat misji. Warszawa: Wydawnictwo Missio-Polonia, 2006. 
Grzybowski, Michał Marian. Duchowieństwo diecezji płockiej: wiek XX. T. 1. Cz. 2. Płock: Kronos, 2007. 7-9.

Jabłoński, Franciszek. „Wkład Kościoła w Polsce w dzieło misyjne w XIX w.” Misje w XIX wieku. Wybrane zagadnienia. Red. Piotr Artur Sokołowski. Pieniężno: Misyjne Seminarium Duchowne Księży Werbistów, 2008. 207-236.

Kisiel, Dariusz. „Biskup Profesor Jan Wosiński. Ojciec Duchowny (1914-1996).” Mistrzowie i nauczyciele. Profesorowie Seminarium Duchownego w Ptocku 1965-2000. Red. Ireneusz Mroczkowski. Płock: Płocki Instytut Wydawniczy, 2001. 25-45.

Klimkiewicz, Witold. Kardynat Ledóchowski na tle swej epoki. T. 1-3. Poznań: Księgarnia Świętego Wojciecha, 1987.

Kluj, Wojciech. Teologiczne podstawy misji wedtug Jana Pawła II. Warszawa: IPJP2, 2008.

Kluz, Władysław. Czterdzieści siedem lat życia. Niepokalanów: Wydawnictwo Ojców Franciszkanów, 2006.

Kłoczowski, Jan Andrzej. „Wstęp do pielgrzymki Jana Pawła II do Polski: 2-10 czerwca 1979.” Jan Paweł II, Dzieła zebrane. Homilie i przemówienia z pielgrzymek-Europa. Polska. T. 9. Cz. 1. Kraków: Wydawnictwo M, 2008. 17-21.

Krzymkowska, Małgorzata. „Chronologia życia i działalności błogosławionej Marii Teresy Ledóchowskiej. Maria Teresa Ledóchowska i misje.” W nurcie zagadnień posoborowych. Red. Bogdan Bejze. T. 9. Warszawa: Wydawnictwo Sióstr Loretanek, 1977. 9-14.

Nowak, Adam. „Rodzinne środowisko Marii Teresy Ledóchowskiej. Maria Teresa Ledóchowska i misje." W nurcie zagadnień posoborowych. Red. Bogdan Bejze. T. 9. Warszawa: Wydawnictwo Sióstr Loretanek, 1977. 15-22.

Polscy misjonarze w świecie. 50 lat od Dekretu soborowego „Ad gentes”. T. 1-3. Górna Grupa: Verbinum, 2015.

Różański, Jarosław. Wokół koncepcji inkulturacji. Warszawa: Wydawnictwo UKSW, 2008.

Różański, Jarosław. Misje a promocja ludzka. Warszawa: Missio-Polonia, 2001.

Rutowski, Tadeusz. „Filozoficzno-teologiczne poglądy Pawła Włodkowica (Na podstawie pism 'Saevientibus' i 'Opinio Ostientis.').” Studia Plockie (1985) 13: 184-194.

Ryłko, Stanisław. „Wstęp do pielgrzymek Jana Pawła II do Polski.” Jan Paweł II. Dzieła zebrane. Homilie i przemówienia z pielgrzymek - Europa. Polska. T. 9. Cz. 1. Kraków: Wydawnictwo M, 2008. 13-14.

Sotowski, Paulin. Opowieść o św. Maksymilianie. Niepokalanów: Wydawnictwo Ojców Franciszkanów, 2011.

Tomaszewski, Czesław. „Błogosławiony Jan Beyzym SJ.” Dostęp 22 lutego 2020. <https://missio. org.pl/pontyfikat/misyjni-swieci/misjonarze/85-blogoslawiony-jan-beyzym-sj>

Urban, Wincenty. „Akcja misyjna Kościoła katolickiego w Polsce.” Księga tysiąclecia katolicyzmu w Polsce. Red. Marian Rechowicz [i inni]. Lublin: TN KUL, 1969. 585-638.

Wosiński, Jan. „Wkład bł. Maksymiliana Kolbe w misyjne dzieło Kościoła.” Collectanea Theologica 42.4 (1972). 5-14.

Wysocki, Marcin. „Aktualność ewangelizacyjnej misji Kościoła w świetle inicjatyw apostolskich św. Maksymiliana Marii Kolbego.” Lumen Gentium (2018) 2. 85-103.

Zagrodzki, Wojciech. Człowiek droga Kościoła. Jan Paweł II w Polsce. Kraków: Wydawnictwo Homo Dei, 2002.

Grzegorz Adamiak, kapłan diecezji płockiej, doktor z zakresu misjologii, absolwent UKSW. 